\title{
Problems and opportunities of women SHGs in entrepreneurship development
}

See end of the paper for authors' affiliations BINAPANI DEKA

Krishi Vigyan Kendra (Assam Agricultural University), JORHAT (ASSAM) INDIA Email : dbinapani@ymail.com
ABSTRACT : Empowerment of rural women has emerged as an important issue in today. The economic empowerment of rural women is being regarded as independence for rural women. Rural women are becoming economically independent and providing employment opportunities to others through involving in micro entrepreneurship. Women's entrepreneurship contributes to the economic well-being of the family and communities and also reduces poverty. Self-help groups (SHGs) have smoothened the way for economic empowerment. Economic empowerment of rural women led to development of family, community, society, state and nation therefore it is very necessary to give keen of our attention over empowerment of women in the rural area for the real development of our country in all spheres. An SHG entrepreneur is someone that organizes, manages, and assumes the risk of a business enterprise. Today, more women are breaking free from the traditional, gender-specific roles and venturing into the business world. This study deals with empowerment of rural women through micro entrepreneurship development among rural women. This study was carried out to know the socio- economic background of the women SHG's, their knowledge, skills and earning capacity. The study also looked at the money management practices of women SHG members and their problems. On the basis of the findings that revealed limited knowledge of the women regarding value for savings, account keeping and financial liabilities. Only a few SHGs were found economically proficient.

KEY WORDS: Problems, Opportunities, SHGs, Entrepreneurship development.

HOW TO CITE THIS PAPER : Deka, Binapani and Borgohain, Rupam (2016). Problems and opportunities of women SHGs in entrepreneurship development. Asian J. Home Sci., 11 (2) : 331-334, DOI: 10.15740/HAS/AJHS/11.2/331-334. 